\title{
The association of apoptotic protein expressions sensitive to apoptosis gene, p73 and p53 with the prognosis of cervical carcinoma
}

This article was published in the following Dove Press journal:

OncoTargets and Therapy

26 November 2014

Number of times this article has been viewed

\author{
Pinar Mega Tiber' \\ Latife Baloglu² \\ Sevgi Ozden ${ }^{3}$ \\ Zerrin Ozgen ${ }^{4}$ \\ Hazan Ozyurt ${ }^{3}$ \\ Makbule Eren ${ }^{3}$ \\ Oya Orun'
}

'Department of Biophysics, Marmara University, School of

Medicine, Maltepe, Istanbul, Turkey;

${ }^{2}$ Laboratory Medicine, Karolinska

Institute Biomedical Laboratory

Science, Stockholm, Sweden;

${ }^{3}$ Clinic of Radiation Oncology, Dr Lutfi Kirdar Kartal Education and

Research Hospital, Istanbul, Turkey;

${ }^{4}$ Department of Radiation Oncology,

Marmara University, School of

Medicine, Kaynarca, Istanbul, Turkey

Correspondence: Oya Orun

Department of Biophysics,

Marmara University, School of Medicine,

Maltepe Basibuyuk Sok,

34854 Istanbul, Turkey

Tel +90216 42I 2222

Email oyaorun@yahoo.com;

oakalin@marmara.edu.tr
Objective: To evaluate the expressions of several apoptotic pathway proteins in relation to clinical parameters and survival in patients with cervical carcinoma.

Methods: A total of 20 patients with clinically advanced staged carcinoma of cervix (International Federation of Gynecology and Obstetrics [FIGO] stage IIB-IVA) aged from 40 to 75 years were included in this study. The expression profile of anti-apoptotic protein (sensitive to apoptosis gene [SAG]), mitochondrial apoptotic proteins (B-cell lymphoma-extra-large [Bcl-xL] and Bcl-2 homologous antagonist/killer [Bak]), and tumor suppressor proteins (p73 and p53) were examined by real-time polymerase chain reaction experiments along with their relation to clinical parameters and survival analyses during follow-up for 5 to 8 years.

Results: No significant difference was found in the expressions of SAG, Bcl-xL, Bak, p73 and p53 proteins with respect to stage and grade of tumor. A significant positive correlation was noted between $S A G$ and $B c l-x L$ genes $(r=0.752, P<0.001)$ and between $S A G$ and $B a k$ genes ( $r=0.589, P=0.006$ ). Among genes determined to be significantly associated with overall survival in the univariate analysis ( $P=0.026$ for $S A G, P=0.002$ for $B c l-x L$, and $P=0.027$ for $p 53$ ), only $p 53$ was identified as the significant predictor in the multivariate analysis (hazard ratio: 8.53, 95\% confidence interval: $1.34-54.2, P=0.023)$.

Conclusion: In conclusion, our findings demonstrated a reverse correlation of $S A G, B c l-x L$, and p53 expressions with overall survival of patients. No association of apoptotic pathway proteins with clinicopathological characteristics of cervical carcinoma patients was noted. Low $S A G$, $B c l-x L$, and $p 53$ expression levels revealed to be useful as prognostic predictors in patients with cervical carcinoma.

Keywords: sensitive-to-apoptosis gene, apoptosis, p53, p73, cervical carcinoma

\section{Introduction}

Cervical cancer, the most common gynecological malignant disorder worldwide, remains as the major cause of cancer related mortality among women in the developing countries. ${ }^{1,2}$ Radiotherapy with or without cisplatin based chemotherapy has been the primary treatment of choice on locally advanced stage cervical carcinoma, though this is only effective with low-resistance cells. Tumor response and survival rates are highly variable among individuals with different tumor radiosensitivities. Tumor radiosensitivity is regulated by several factors, such as DNA repair mechanisms, cell cycle distribution, and genetic instability, yet none of these parameters is predictive of tumor sensitivity in vivo. ${ }^{3,4}$

Carcinogenesis in cancer of the cervix is predominantly the result of activities of the human papillomavirus (HPV) oncogenes $E 6$ and $E 7$, which disturb the regulation of 
cell cycle and apoptotic pathways, especially via intervention in p53 and $\mathrm{Rb}$ pathways, respectively. ${ }^{5,6}$ Even though the main action mechanism of E6 is its interference with p53 function, there are also reports of p53-independent actions. ${ }^{6}$ It has also been hypothesized that p73 may play a role in inducing apoptosis and cell cycle arrest in response to radiation, in a p53-independent manner, by having a compensatory role in p53 dysfunction via triggering p53-independent apoptosis or cell cycle effectors in cancer cells. ${ }^{7}$

Regarding apoptotic pathways, B-cell lymphoma 2 (Bcl-2) family proteins have been of special importance within the large family of apoptosis-related proteins, including anti-apoptotic prosurvival proteins (such as Bcl-2 and B-cell lymphoma-extra-large [Bcl-xL]) and pro-apoptotic proteins (such as $\mathrm{BH} 3$-only proteins, BCL-2-antagonist/ killer [Bak] and BCL-2-associated X protein [Bax]), as they form crossroads for both extrinsic and intrinsic pathways. ${ }^{8}$ It has been considered that the effect of anticancer treatmentinduced apoptosis may be regulated by the balance between pro- and anti-apoptotic ratio of mitochondrial proteins, such as Bcl-2, Bcl-xL, Bak or Bax. ${ }^{9}$ Studies on the therapeutic effects of p53 or Bcl-2 family are inconsistent, yet the role of Bcl-2 as a prognostic factor is more established. ${ }^{10,11}$

One of the novel anti-apoptotic proteins with prognostic potential has been SAG/ROC/Rbx/Hrt (sensitive to apoptosis gene/regulators of cullins/RING box protein). SAG is a member of RING finger family and its expression is induced by mitogenic stimulation. ${ }^{12}$ It has been proposed that SAG might be an attractive target for anticancer therapy and a valuable factor in discerning the prognosis of the disease $\mathrm{e}^{13,14}$ given its well-documented radiosensitizing property and likely role as a protective agent against apoptosis induced by ionizing-radiation. ${ }^{15}$

The possible involvement of cell cycle, DNA repair, and apoptotic genes in the progress of cancer is still of special interest. Therefore, the present study focuses on the potential effects of anti-apoptotic protein (SAG), mitochondrial apoptotic proteins (Bcl-xL and Bak), and tumor suppressor proteins (p73 and p53) in response to radio/chemotherapy in relation to clinical parameters and survival in patients with cervical carcinoma over a follow-up period of 5 to 8 years.

\section{Materials and methods}

\section{Study population}

A total of 20 patients with clinically advanced staged carcinoma of the cervix (International Federation of Gynecology and Obstetrics [FIGO] stage IIB-IVA) aged 40 to 75 years and 20 patients with prior gynecological operations due to causes other than cancer were included in this study. The expression profile of anti-apoptotic protein SAG, mitochondrial apoptotic proteins $\mathrm{Bcl}-\mathrm{xL}$ and Bak, and tumor suppressor proteins p73 and p53 were examined in real-time polymerase chain reaction (PCR) experiments in terms of their relation to clinical parameters and survival during the follow-up period.

Tissue samples were collected from patients after the receipt of formal ethical approval from the appropriate ethical committees related to the Marmara University School of Medicine. All patients provided written informed consent before undergoing diagnostic cervical biopsy. The median follow-up time for surviving patients was 60 months. The clinicopathological features and survival times of all the patients are presented in Table 1.

\section{Therapy}

The study subjects with histologically proven squamous cell carcinoma of the uterine cervix were treated using definitive radiotherapy with concomitant cisplatin on a weekly basis in the Radiation Oncology Department of Kartal Education and Research Hospital. Pretreatment staging and evaluation included a history, a physical and gynecological examination (under anesthesia if necessary), routine blood counts, kidney function tests, chest X-rays, and total abdominal computed tomography (CT) or magnetic resonance imaging (MRI). Patients were staged jointly by radiation and gynecologic oncologists according to the FIGO classification.

Patients were treated with a combination of external beam radiation therapy and high-dose-rate remote control afterloading intra-cavitary radiation therapy. External pelvic irradiation was administered with $15 \mathrm{MV}$ photons or cobalt-60 gamma rays at a dose of 2 Gy per fraction, five fractions per week, for a total dose of 50. The intra-cavitary radiation therapy was administered with high-dose-rate Curietron Cesium-137 sources. A total dose of 20 Gy was delivered as brachytherapy at point $\mathrm{A}$ in three fractions. A short infusion of cisplatin ( $40 \mathrm{mg} / \mathrm{m}^{2}$, once per week) was applied concomitantly during external radiotherapy.

\section{Follow-up}

The follow-up period was defined as the time interval between the surgery and last medical appointment or death, and involved a 5 to 8-year period. Regular follow-up consisted of physical examinations, with 3-month intervals during the first 2 years, and 6-month intervals thereafter. Patients in whom signs of metastatic disease were present underwent further investigations. Disease relapse was defined as either local recurrence or the development 
Table I Clinicopathological features and respective survival times of 20 patients with cervical carcinoma

\begin{tabular}{|c|c|c|c|c|c|c|}
\hline Patient number & Age & Stage & Histological type & Differentiation & Metastasis & $\begin{array}{l}\text { Survival time } \\
\text { (months) }\end{array}$ \\
\hline I & 75 & IVA & Invasive squamous cell & Poor & Bone & 20.8 \\
\hline 2 & 42 & IIIB & Large cell & Poor & Para-aortic In & 84.3 \\
\hline 3 & 47 & IIIB & Large cell & Medium & & 89.1 \\
\hline 4 & 75 & IIIB & Large cell & Medium & & 81.2 \\
\hline 5 & 40 & IIB & Invasive squamous cell & Medium & & 89.1 \\
\hline 6 & 63 & IIB & Invasive squamous cell & Well & & 89.4 \\
\hline 7 & 39 & IIB & Large cell & Poor & Lung & 47.5 \\
\hline 8 & 40 & IIIB & Large cell & Poor & Multiple organ & 57.7 \\
\hline 9 & 45 & IIIB & Large cell & Poor & & 45.3 \\
\hline 10 & 55 & IIIB & Large cell & Poor & Para-aortic In & 22.7 \\
\hline 11 & 74 & IIIB & Invasive squamous cell & Poor & Lung & 4.5 \\
\hline 12 & 75 & IVA & Large cell & Poor & Multiple organ & 33.4 \\
\hline 13 & 48 & IIB & Invasive squamous cell & Medium & & 81.7 \\
\hline 14 & 50 & IIB & Invasive squamous cell & Medium & & 90.1 \\
\hline 15 & 57 & IIB & Large cell & Poor & & 91.7 \\
\hline 16 & 57 & IIIB & Large cell & Poor & & 90.3 \\
\hline 17 & 57 & IIIB & Large cell & Poor & Lung & 45.1 \\
\hline 18 & 50 & IIB & Invasive squamous cell & Medium & & 87.4 \\
\hline 19 & 68 & IIIB & Invasive squamous cell & Poor & & 86.3 \\
\hline 20 & 70 & IVA & Large cell & Well & & 26.2 \\
\hline
\end{tabular}

Abbreviation: In, lymph node.

of metastasis, and was determined through clinical and radiographic studies using CTs or MRIs, or by tissue biopsy, invariably. Local-free survival time (months), disease-free survival time (months) and overall survival (OS) time (months) were evaluated, and the patients' statuses were followed until December 2012.

\section{Real-time PCR}

Total ribonucleic acid (RNA) was extracted from biopsies of 20-30 mg of cervical tumor or normal cervical tissue samples and then stored in RNAlater solution until the day of experiment (for up to 4 weeks). Total RNA was purified using the RNeasy Mini Kit (Qiagen NV, Venlo, the Netherlands) according to the manufacturer's instructions. Samples were treated on column with DNase I (Qiagen) to remove any possible contaminating genomic DNA. RNA samples were quantified by optical density measurements and their purity was assessed using agarose gel electrophoresis and PCR amplifications. One microgram of total RNA was reverse transcribed using the Transcriptor High Fidelity cDNA Synthesis kit (Hoffman-La Roche Ltd, Basel, Switzerland) according to the manufacturer's guidelines. cDNA's were diluted ten times and used as a template in real-time PCR reactions. Real-time PCR was applied using the LightCycler 480 instrument and LightCycler 480 SYBR Green I Master kit (Hoffman-La Roche Ltd). SAG expression was analyzed using the following primers: forward (5'-CGG GAT CCA
TGG CCG ACG TGG AAG-3') and reverse (5'-CGA AGC TTT CAT TTG CCG ATT CTT TGG AC-3'). The expressions of other apoptotic pathway genes (Bcl-xL, Bak, p53 and p73) were analyzed using the following primers: Bcl-xL forward (5'-CCA GAA GGG ACT GAA TCG-3') and reverse (5'-CCT TGT CTA CGC TTT CCA C-3'); Bak forward (5'-GAC CCA GAG ATG GTC ACC TT- $3^{\prime}$ ) and reverse (5'-TCA TAG CGT CGG TTG ATG T-3'); p53 forward (5'-AGG CCT AAC TCA AGG AT- $3^{\prime}$ ) and reverse (5'-CCC TTT TTG GAC TTC AGG TG-3'); 73 forward (5'-GCT CGG GAG GGA CTT CAA $\left.-3^{\prime}\right)$ and reverse (5'-CTC ATA GGG CAC CAC GAC $-3^{\prime}$ ). $\beta$-actin gene expression was used in parallel reactions as an internal PCR control. The primer sequences for the housekeeping gene $\beta$-actin were $\beta$-act forward (5'-CCA ACC GCG AGA AGA TGA-3') and $\beta$-act reverse ( $5^{\prime}$-CCA GAG GCG TAC AGG GAT AG-3'). Relative expression levels were determined using the Pfaffl method, where delta $C_{t}$ values were calculated for genes of interest between tumor and normal tissues and normalized relative to the changes in the house-keeping gene $\beta$-actin. Tumor and normal tissues were paired according to the closest age.

\section{Statistical analysis}

Statistical analysis was performed using MedCalc Statistical Software version 12.7.7 (MedCalc Software bvba, Ostend, Belgium; http://www.medcalc.org; 2013). Chi-square test was used for the comparison of categorical data, while 
Spearman's correlation analysis was used to analyze correlations between gene expressions. The Breslow test was used to determine the relation between gene expressions and survival via univariate analysis. Survival analysis was performed using Kaplan-Meier analysis and comparisons were made using the log-rank test. Correlates of survival were determined via Cox-regression analysis. Data were expressed as mean \pm standard deviation (SD), minimum-maximum (min-max), percent (\%) and 95\% confidence interval $(\mathrm{CI})$ where appropriate. $P<0.05$ was considered statistically significant.

\section{Results}

\section{Gene expression according to patient age and tumor characteristics}

Ratio of fold changes in gene expression relative to the house-keeping gene were evaluated, with expressions classified as "high" when below the median value, or "low" when the reverse was true. The median values for fold changes in each group were determined as 0.053, 3.873, 2.813, 0.047, 2.882 for SAG, Bcl-xL, Bak, p53 and p73 expressions, respectively.

No significant differences were noted in the high, low, or overall expression of the SAG, Bcl-xL, Bak, p73 and p53 genes with respect to age ( $\leq 50$ versus [vs] $>51$ years), stage of tumor (IIB vs IIIB-IVA), and grade of tumor (poor vs moderate-well) (Table 2).

\section{Correlation between gene expressions}

A significant positive correlation was noted between the SAG and Bcl-xL genes $(r=0.752, P<0.001)$ and between the SAG and Bak genes $(r=0.589, P=0.006)$. The Spearman correlation test also revealed a close link between two well known, oppositely working pro- and anti-apoptotic proteins: $\mathrm{Bcl}-\mathrm{xL}$ and Bak from the Bcl-2 family $(r=0.550, P=0.012)$, and two tumor suppressors, $\mathrm{p} 53$ and p73, of the same family $(r=0.562, P=0.010$ ), as expected (Table 3 ).

\section{Relationship between gene expression and survival}

Median (min-max) OS was significantly longer in lower expression of SAG (89.3 (22.7-91.7) vs 46.4 (4.5-89.1) months, $P=0.026)$, Bcl-xL (89.1 (47.5-91.7) vs 45.1 (4.5-87.4) months, $P=0.002)$ and p53 (86.3 (22.7-91.7) vs 45.3 (4.5-89.4) months, $P=0.027$ ) when compared to higher expressions of each gene (Figure 1 and Table 4).

No significant association was noted between the Bak and p73 gene expressions and OS, and no gene expressions

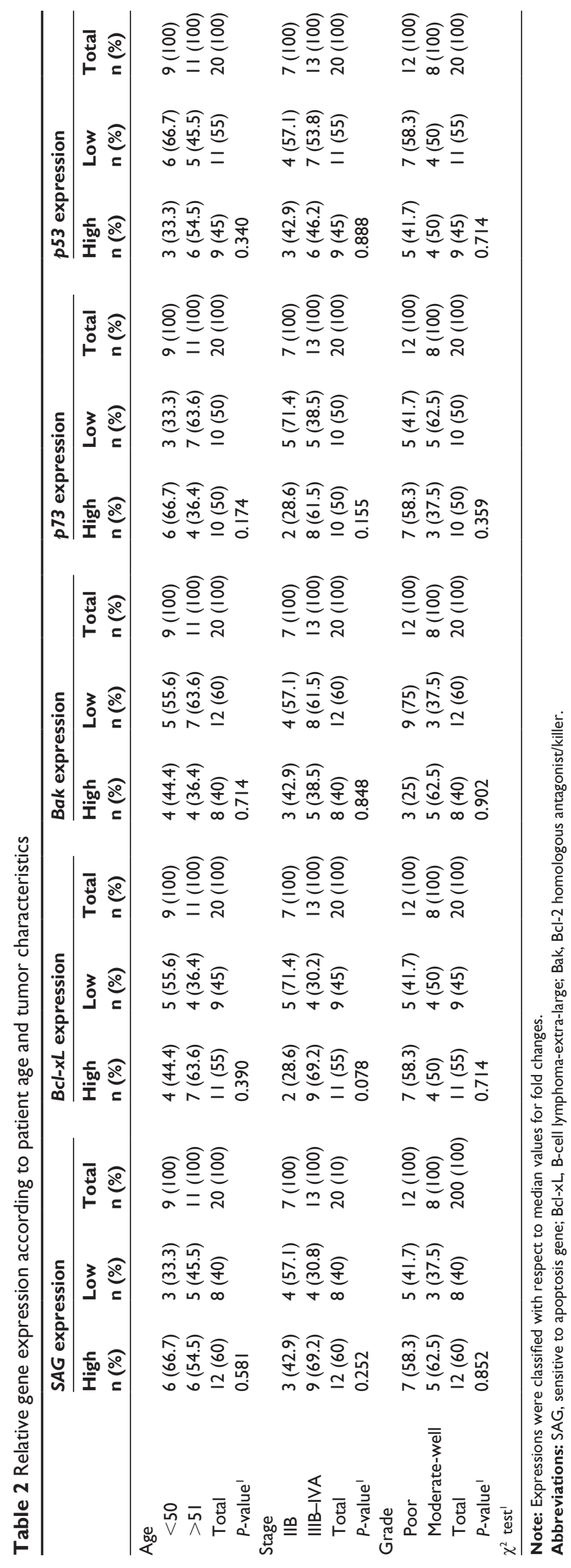


Table 3 Correlations between genes according to Spearman analysis

\begin{tabular}{|c|c|c|c|c|c|}
\hline Spearman's rho & SAG & Bcl-xL & Bak & p73 & p53 \\
\hline \multicolumn{6}{|l|}{$\overline{S A G}$} \\
\hline Correlation & 1.000 & 0.752 & 0.589 & 0.400 & 0.368 \\
\hline \multicolumn{6}{|l|}{ Coefficient } \\
\hline$P$-value & - & $<0.00 I^{*}$ & $0.006 *$ & 0.081 & 0.110 \\
\hline \multicolumn{6}{|l|}{$B C l-x L$} \\
\hline Correlation & 0.752 & 1.000 & 0.550 & 0.389 & 0.417 \\
\hline \multicolumn{6}{|l|}{ Coefficient } \\
\hline$P$-value & $<0.00 I^{*}$ & - & $0.012^{*}$ & 0.090 & 0.068 \\
\hline \multicolumn{6}{|l|}{ Bak } \\
\hline Correlation & 0.589 & 0.550 & 1.000 & 0.233 & 0.447 \\
\hline \multicolumn{6}{|l|}{ Coefficient } \\
\hline$P$-value & $0.006 *$ & $0.012 *$ & - & 0.323 & $0.048^{*}$ \\
\hline \multicolumn{6}{|l|}{ p73 } \\
\hline Correlation & 0.400 & 0.389 & 0.233 & 1.000 & 0.562 \\
\hline \multicolumn{6}{|l|}{ Coefficient } \\
\hline$P$-value & 0.081 & 0.090 & 0.323 & - & $0.010 *$ \\
\hline \multicolumn{6}{|l|}{ p53 } \\
\hline Correlation & 0.368 & 0.417 & 0.447 & 0.562 & 1.000 \\
\hline \multicolumn{6}{|l|}{ Coefficient } \\
\hline$P$-value & 0.110 & 0.068 & $0.048 *$ & $0.010 *$ & - \\
\hline
\end{tabular}

Note: $* P<0.05$ was considered statistically significant.

Abbreviations: SAG, sensitive to apoptosis gene; Bcl-xL, B-cell lymphoma-extralarge; Bak, Bcl-2 homologous antagonist/killer.

were associated with local-recurrence free survival (months) and disease-free survival (months) (Table 4).

The Kaplan-Meier survival curves of the log-rank analysis data showed that low OS expression levels might well be related to high SAG $(P=0.026), \mathrm{Bcl}-\mathrm{xL}(P=0.002)$, and $\mathrm{p} 53$ $(P=0.027)$ expression levels (Figure 2$)$.

\section{Multivariate analysis for genes as predictive factors of OS}

Among the genes determined to be significantly associated with OS in the univariate analysis (SAG, Bcl-xL, and p53),

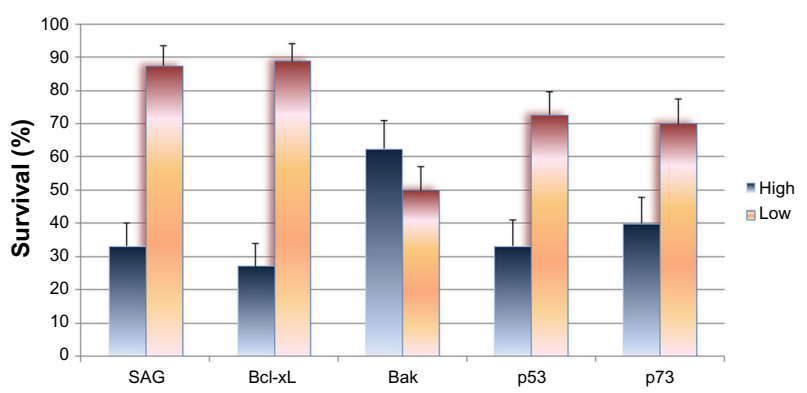

Figure I Comparison of survival up to 8 years follow-up in terms of the study's different parameters.

Note: Expressions were normalized with respect to the house-keeping control and assignments were made relative to their median values.

Abbreviations: SAG, sensitive to apoptosis gene; $\mathrm{Bcl}-\mathrm{xL}, \mathrm{B}$-cell lymphoma-extralarge; Bak, Bcl-2 homologous antagonist/killer.
Table 4 Univariate analysis for the relationship between gene expression and survival

\begin{tabular}{|c|c|c|c|}
\hline \multirow[t]{2}{*}{ Variables } & $\begin{array}{l}\text { Local-recurrence } \\
\text { free survival } \\
\text { time (months) }\end{array}$ & $\begin{array}{l}\text { Disease- } \\
\text { free survival } \\
\text { time (months) }\end{array}$ & $\begin{array}{l}\text { Overall } \\
\text { survival time } \\
\text { (months) }\end{array}$ \\
\hline & $\begin{array}{l}\text { Median } \\
(\min -\max )\end{array}$ & $\begin{array}{l}\text { Median } \\
\text { (min-max) }\end{array}$ & $\begin{array}{l}\text { Median } \\
\text { (min-max) }\end{array}$ \\
\hline \multicolumn{4}{|l|}{ SAG } \\
\hline $\begin{array}{l}\text { High expression } \\
(\mathrm{n}=8)\end{array}$ & $\begin{array}{l}64 \\
(7.0-77.7)\end{array}$ & $\begin{array}{l}34.5 \\
(2.6-89.1)\end{array}$ & $\begin{array}{l}46.4 \\
(4.5-89.1)\end{array}$ \\
\hline $\begin{array}{l}\text { Low expression } \\
(n=12)\end{array}$ & $\begin{array}{l}71 \\
(17.4-74.6)\end{array}$ & $\begin{array}{l}89.3 \\
(|6-9| .7)\end{array}$ & $\begin{array}{l}89.3 \\
(22.7-91.7)\end{array}$ \\
\hline$P$-value ${ }^{\mathrm{a}}$ & 0.278 & 0.213 & $0.026 *$ \\
\hline \multicolumn{4}{|l|}{ Bcl-xL } \\
\hline $\begin{array}{l}\text { High expression } \\
(\mathrm{n}=\mathrm{II})\end{array}$ & $\begin{array}{l}64 \\
(7-77.7)\end{array}$ & $\begin{array}{l}32.4 \\
(2.6-87.4)\end{array}$ & $\begin{array}{l}45.1 \\
(4.5-87.4)\end{array}$ \\
\hline $\begin{array}{l}\text { Low expression } \\
(\mathrm{n}=9)\end{array}$ & $\begin{array}{l}71.4 \\
(47.5-74.6)\end{array}$ & $\begin{array}{l}89.1 \\
(30-91.7)\end{array}$ & $\begin{array}{l}89.1 \\
(47.5-91.7)\end{array}$ \\
\hline$P$-value ${ }^{\mathrm{a}}$ & 0.114 & 0.056 & $0.002 *$ \\
\hline \multicolumn{4}{|l|}{ Bak } \\
\hline $\begin{array}{l}\text { High expression } \\
(\mathrm{n}=8)\end{array}$ & $\begin{array}{l}72.0 \\
(7.0-74.6)\end{array}$ & $\begin{array}{l}84.3 \\
(2.6-91.7)\end{array}$ & $\begin{array}{l}84.3 \\
(4.5-91.7)\end{array}$ \\
\hline $\begin{array}{l}\text { Low expression } \\
(\mathrm{n}=12)\end{array}$ & $\begin{array}{l}65.1 \\
(9.0-77.7)\end{array}$ & $\begin{array}{l}47.1 \\
(16-90.0)\end{array}$ & $\begin{array}{l}69.7 \\
(20.8-90.3)\end{array}$ \\
\hline$P$-value ${ }^{a}$ & 0.713 & 0.153 & 1.00 \\
\hline \multicolumn{4}{|l|}{ p73 } \\
\hline $\begin{array}{l}\text { High expression } \\
(\mathrm{n}=10)\end{array}$ & $\begin{array}{l}65.1 \\
(7.0-72.9)\end{array}$ & $\begin{array}{l}40.9 \\
(2.6-89.1)\end{array}$ & $\begin{array}{l}52.6 \\
(4.5-89.1)\end{array}$ \\
\hline $\begin{array}{l}\text { Low expression } \\
(\mathrm{n}=10)\end{array}$ & $\begin{array}{l}70.2 \\
(10.6-77.7)\end{array}$ & $\begin{array}{l}86.9 \\
(16-91.7)\end{array}$ & $\begin{array}{l}86.9 \\
(22.7-91.7)\end{array}$ \\
\hline$P$-value ${ }^{\mathrm{a}}$ & 0.226 & 0.124 & 0.212 \\
\hline \multicolumn{4}{|l|}{ p53 } \\
\hline $\begin{array}{l}\text { High expression } \\
(\mathrm{n}=9)\end{array}$ & $\begin{array}{l}70.5 \\
(7.0-77.7)\end{array}$ & $\begin{array}{l}32.4 \\
(2.6-89.4)\end{array}$ & $\begin{array}{l}45.3 \\
(4.5-89.4)\end{array}$ \\
\hline $\begin{array}{l}\text { Low expression } \\
(\mathrm{n}=\mathrm{II})\end{array}$ & $\begin{array}{l}68.9 \\
(17.4-74.6)\end{array}$ & $\begin{array}{l}86.3 \\
(|6-9| .7)\end{array}$ & $\begin{array}{l}86.3 \\
(22.7-91.7)\end{array}$ \\
\hline$P$-value ${ }^{a}$ & 0.253 & 0.445 & $0.027^{*}$ \\
\hline
\end{tabular}

Notes: aBreslow test. ${ }^{*}<0.05$ was considered statistically significant. Abbreviations: SAG, sensitive to apoptosis gene; Bcl-xL, B-cell lymphoma-extralarge; Bak, Bcl-2 homologous antagonist/killer.

only p53 was identified as a significant predictor of OS in the multivariate analysis, with an 8.53 -fold increase in the OS in low over high expression of the p53 gene (hazard ratio, 8.53, 95\% CI: $1.34-54.2, P=0.023$ ) (Table 5).

\section{Discussion}

Our findings revealed that while no significant differences were noted in the expression profiles of the apoptotic pathway proteins with respect to age ( $\leq 50 \mathrm{vs}>51$ years), stage (IIB vs IIIB-IVA), and grade of tumor (poor vs moderate-well), a significant positive correlation was noted between the SAG/ Bcl-xL, SAG/Bak, Bcl-xL/Bak, and p53/p73 genes. Low expression of SAG, Bcl-xL, and p53 proteins was associated with a significantly longer OS duration in the univariate analysis, whereas only p53 was confirmed to be a significant 
A

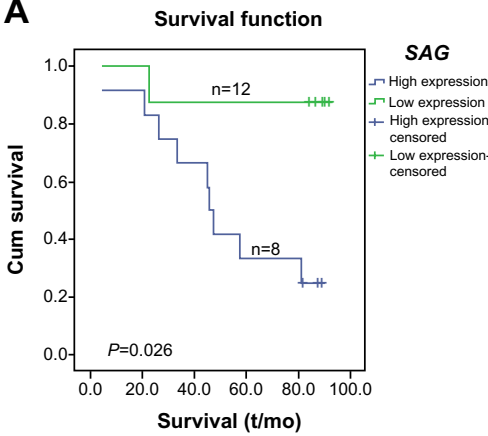

B

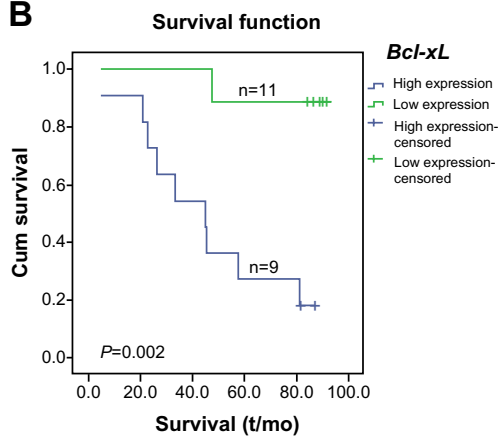

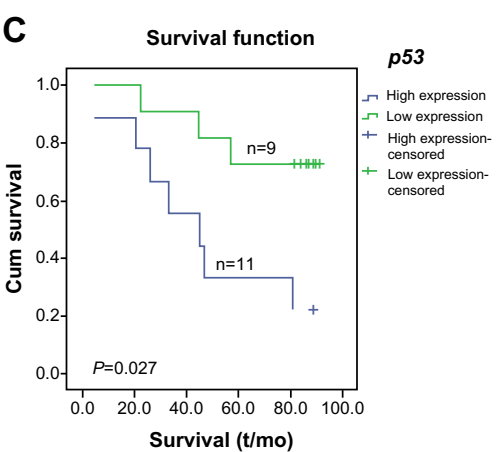

Figure 2 Kaplan-Meier survival curves with univariate log-rank comparisons at the end of 8 years. Note: (A) Sensitive to apoptosis (SAG); (B) B-cell lymphoma-extra large (Bcl-xL); (C) p53.

Abbreviations: Cum, cumulative; $t$, time; mo, months.

predictor of OS in the multivariate analysis, with an 8.53 -fold increase in OS in low over high expression of the $\mathrm{p} 53$ gene.

In a previous study, our group investigated the prognostic role of SAG in advanced stage rectal cancers and found a significant correlation between expression levels and OS time.${ }^{16}$ In this study, we have demonstrated that SAG has a similar outcome in cases of cervical carcinoma, which is a different type of cancer with a virus-based origin.

Neither local-recurrence free survival nor disease-free survival was associated with the expression of the apoptotic pathway proteins. In the univariate analysis, expressions of anti-apoptotic protein SAG, mitochondrial apoptotic protein Bcl-xL, and tumor suppressor protein p53 were found to be closely related to OS rate, along with significant correlation between SAG and Bcl-xL genes, while the expression of p53 appeared to be a strong candidate to estimate prognosis of cervical cancer, based on multivariate analysis.

p53 is a well-known tumor suppressor protein that can mobilize two competing pathways, cell cycle arrest or cell death, depending on the cytotoxic effect, status of the cell cycle, repair mechanisms, and checkpoints. Prevention of cell cycle arrest by blocking the related genes such as p53 can

Table 5 Multivariate analysis for genes predicting overall survival

\begin{tabular}{llll}
\hline Variables & \multicolumn{2}{l}{$\begin{array}{l}\text { Multivariate analysis } \\
\text { Cox regression }\end{array}$} \\
\cline { 2 - 4 } & HR & \multicolumn{1}{c}{$\mathbf{9 5 \%} \mathbf{~ C l}$} & P-value \\
\hline Overall survival & & & \\
SAG & 0.523 & 0.1 I-24.II & 0.740 \\
BCl-xL & 55.27 & $0.84-3632.75$ & 0.060 \\
Bak & 0.176 & $0.025-1.223$ & 0.079 \\
P73 & 2.176 & $0.447-10.61$ & 0.336 \\
P53 & 8.53 & $1.34-54.2$ & 0.023 \\
\hline
\end{tabular}

Note: Significance of model: $P=0.01 \mathrm{I}$.

Abbreviations: SAG, sensitive to apoptosis gene; Bcl-xL, B-cell lymphoma-extra-large; $\mathrm{Bak}, \mathrm{Bcl}-2$ homologous antagonist/killer; $\mathrm{HR}$, hazard ratio; $\mathrm{Cl}$, confidence interval. cause abrogation of repair mechanisms and may eventually lead to cell death. Numerous studies have pointed out that p53 may regulate mitochondrial Bcl-2 family members, both pro- and anti-apoptotic, such as Bak, Bax, Bcl-xL ${ }^{17,18}$ and that p53 can directly initiate the translocalization of proapoptotic members to mitochondria and activates them to trigger mitochondrial leakage. ${ }^{1}$ p53 function, on the other hand, is regulated by post-translational modifications such as phosphorylation, acetylation, and ubiquitination. Ubiquitin-mediated degradation of p53 promoted by E6 causes reduced p53 activity in HPV-infected cervical carcinoma, and a compensatory role has been proposed for $\mathrm{p} 73$ regarding this issue. ${ }^{6}$

While the pairwise comparison of expression levels showed a significant correlation between the Bak and p73 genes, the results as to the effect of these proteins in prognosis were far from significant in all analyses, likely due to the fact that the proteins' joint effects of expression and action could not be acquired in such a small study size (data not shown).

Our findings accord with the data of other studies that have indicated p53 as a predictor of prognosis in association with OS. ${ }^{19-21}$ The role of $\mathrm{p} 73$, on the other hand, is highly questionable and complex. Although a significant association between the overexpression of $\mathrm{p} 73$ and cellular sensitivity in cervical cancers after radiotherapy has been reported by Liu et al, ${ }^{7}$ no correlation was observed between HPV infections and p 73 expressions in the study. Furthermore, the $\mathrm{p} 73$ gene produces various isoforms, and recent reports indicate that the balance between its two main isoforms, an $\mathrm{NH}_{2}$-terminal truncated form of $\mathrm{p} 73(\Delta \mathrm{Np} 73)$ and full-length wild-type TA isoform of p73 (TAp $73 \alpha$ ), may be influential in clinical outcomes. ${ }^{22,23}$ While no correlation was found in the present study between wild-type p73 expression and survival, this could be due to the lack of isoform analyses in the study. Though the levels of 
expression did not differ significantly with respect to the stage and grade of cervical carcinoma, the expressions of the SAG, Bcl-xL, and p53 proteins displayed longer OS times in our study population. The proposed co-regulatory role of p73, however, could not be verified, as OS and disease-free survival results were very close in terms of both the high and low expression groups. We cannot affirm whether this absence of correlation is due to the counter effects of different isoforms or the study's small sample size as our results were far from significant.

\section{Conclusion}

In conclusion, our findings revealed no association between the apoptotic pathway proteins of study and the clinicopathological characteristics of patients with cervical carcinoma, while a reverse correlation was found to exist for the SAG, $\mathrm{Bcl}-\mathrm{xL}$, and p53 expressions in relation to the longer lifespans of patients. Especially low p53 expression appears to be useful as a prognostic predictor in patients with cervical carcinoma. The positive effect of low SAG expression on survival should further be confirmed by studies with larger cohorts. Even though the origins and applied therapies for cervical cancer are straightforward, the molecular regulatory mechanisms and apoptotic routes related to tumorigenesis require further study to establish improved personalized approaches to such therapy.

\section{Acknowledgments}

The study was supported by the Scientific and Technical Research Council of Turkey (TUBITAK 111S048) and a travel grant by the Scientific Research Project Commission of Marmara University (Project Number: SAG-D100413-0119).

\section{Disclosure}

The authors have no conflicts of interest to disclose.

\section{References}

1. Hougardy BM, Maduro JH, van der Zee AG, Willemse PH, de Jong S, de Vries EG. Clinical potential of inhibitors of survival pathways and activators of apoptotic pathways in treatment of cervical cancer: changing the apoptotic balance. Lancet Oncol. 2005;6(8):589-598.

2. Adhya AK, Srinivasan R, Patel FD. Radiation therapy induced changes in apoptosis and its major regulatory proteins, $\mathrm{Bcl}-2, \mathrm{Bcl}-\mathrm{XL}$, and $\mathrm{Bax}$, in locally advanced invasive squamous cell carcinoma of the cervix. Int J Gynecol Pathol. 2006;25(3):281-287.

3. Rosen EM, Fan S, Rockwell S, Rockwell S, Goldberg ID. The molecular and cellular basis of radiosensitivity: implications for understanding how normal tissues and tumors respond to therapeutic radiation. Cancer Invest. 1999;17(1):56-72.
4. Ogawa K, Murayama S, Mori M. Predicting the tumor response to radiotherapy using microarray analysis. Oncol Rep. 2007;18(5): $1243-1248$.

5. Barbosa LC, da Silva ID, Corêa JC, Ribalta JC. Survivin and telomerase expression in the uterine cervix of women with human papillomavirusinduced lesions. Int J Gynecol Cancer. 2011;21(1):15-21.

6. Hietanen S. Apoptosis in carcinogenesis and chemotherapy of the uterine cervix. In: Chen GG, Lai PBS, editors. Apoptosis in Carcinogenesis and Chemotherapy. Netherlands: Springer; 2009:51-73.

7. Liu SS, Leung RC, Chan KY, et al. p73 expression is associated with the cellular radiosensitivity in cervical cancer after radiotherapy. Clin Cancer Res. 2004;10(10):3309-3316.

8. Dewson G, Kluck RM. Bcl-2 family-regulated apoptosis in health and disease. Cell Health Cytoskelet. 2010;2:9-22.

9. Kim R, Emi M, Tanabe K, Uchida Y, Arihiro K. The role of apoptotic or nonapoptotic cell death in determining cellular response to anticancer treatment. Eur J Surg Oncol. 2006;32(3):269-277.

10. He ZY, Shi CB, Wen H, Li FL, Wang BL, Wang J. Upregulation of p53 expression in patients with colorectal cancer by administration of curcumin. Cancer Invest. 2011;29(3):208-213.

11. Casneuf VF, Fonteyne P, Van Damme N, et al. Expression of SGLT1, Bcl-2 and p53 in primary pancreatic cancer related to survival. Cancer Invest. 2008;26(8):852-859.

12. Sun Y, Tan M, Duan H, Swaroop M. SAG/ROC/Rbx/Hrt, a zinc RING finger gene family: molecular cloning, biochemical properties, and biological functions. Antioxid Redox Signal. 2001;3(4):635-650.

13. Wei D, Sun Y. Small RING finger proteins RBX1 and RBX2 of SCF E3 ubiquitin ligases: the role in cancer and as cancer targets. Genes Cancer. 2010;1(7):700-707.

14. Sun Y, Li H. Functional characterization of SAG/RBX2/ROC2/ RNF7, an antioxidant protein and an E3 ubiquitin ligase. Protein Cell. 2013;4(2):103-116.

15. Kim SY, Yang ES, Lee YS, Lee J, Park JW. Sensitive to apoptosis gene protein regulates ionizing radiation-induced apoptosis. Biochimie. 2011;93(2):269-276.

16. Ozden SA, Ozyurt H, Ozgen Z, et al. Prognostic role of sensitive-to-apoptosis gene expression in rectal cancer. World $J$ Gastroenterol. 2011;17(44):4905-4910.

17. Korsmeyer SJ. BCL-2 gene family and the regulation of programmed cell death. Cancer Res. 1999;59(Suppl 7):1693s-1700s.

18. Hayward RL, Macpherson JS, Cummings J, Monia BP, Smyth JF, Jodrell DI. Enhanced oxaliplatin-induced apoptosis following antisense Bcl-xl down-regulation is p53 and Bax dependent: Genetic evidence for specificity of the antisense effect. Mol Cancer Ther. 2004;3(2): 169-178.

19. Moon A, Won KY, Lee JY, Kang I, Lee SK, Lee J. Expression of BDNF, TrkB, and p53 in early-stage squamous cell carcinoma of the uterine cervix. Pathology. 2011;43(5):453-458.

20. Noske A, Lipka S, Budczies J, et al. Combination of p53 expression and p21 loss has an independent prognostic impact on sporadic colorectal cancer. Oncol Rep. 2009;22(1):3-9.

21. Baalbergen A, Ewing-Graham PC, Eijkemans MJ, Helmerhorst TJ. Prognosis of adenocarcinoma of the uterine cervix: p53 expression correlates with higher incidence of mortality. Int $J$ Cancer. 2007;121(1): 106-110.

22. Liu SS, Chan KY, Leung RC, Law HK, Leung TW, Nqan HY. Enhancement of the radiosensitivity of cervical cancer cells by overexpressing p73alpha. Mol Cancer Ther. 2006;5(5):1209-1215.

23. Soldevilla B, Díaz R, Silva J, et al. Prognostic impact of $\triangle \mathrm{TAp} 73$ isoform levels and their target genes in colon cancer patients. Clin Cancer Res. 2011;17(18):6029-6039. 


\section{Publish your work in this journal}

OncoTargets and Therapy is an international, peer-reviewed, open access journal focusing on the pathological basis of all cancers, potential targets for therapy and treatment protocols employed to improve the management of cancer patients. The journal also focuses on the impact of management programs and new therapeutic agents and protocols on patient perspectives such as quality of life, adherence and satisfaction. The manuscript management system is completely online and includes a very quick and fair peer-review system, which is all easy to use. Visit http://www.dovepress.com/testimonials.php to read real quotes from published authors.

Submit your manuscript here: http://www.dovepress.com/oncotargets-and-therapy-journal 